\title{
The Impact of Fiscal Policy on Welfare Improvement in Indonesia: Study of Impact of Premium Assistance Beneficiaries on The National Health Insurance, Physical Special Allocation Fund for Health Sector, Education Sector, and Village Funds to Human Development Index
}

\author{
Ahmad Nawawi ${ }^{1}$, Wihana Kirana Jaya², Mulyadi Sumarto², Evita Hanie Pangaribowo ${ }^{3}$ \\ 1Doctoral Program of Leadership and Policy Innovation, The Graduate School of Universitas Gadjah Mada, \\ Yogyakarta, Indonesia, ${ }^{2}$ Faculty of Social and Political Sciences, Universitas Gadjah Mada, Yogyakarta, \\ Indonesia, ${ }^{3}$ Faculty of Geography, Universitas Gadjah Mada, Yogyakarta, Indonesia
}

Corresponding Author: Ahmad Nawawi (email: ahmadnawawi@mail.ugm.ac.id)

\begin{abstract}
One of the objectives of the fiscal policy is to improve public welfare. Still, there are funding constraints to improve welfare in some countries. Therefore, fiscal management to increase welfare must be implemented efficiently and effectively. In this research, to improve welfare, the fiscal policy will be focused on health, education and community empowerment which are the components of the HDI. This research used quantitative method with regression equation to explain the impact of fiscal and social policy, in the form of Recipients of Health Insurance Contribution Assistance (Penerima Bantuan Iuran Jaminan Kesehatan Nasional/ PBI JKN), physical special allocation found (Dana Alokasi Khusus/DAK) for health and education sector, village fund, region's budget expenditure, locally generated revenue (Pendapatan Asli Daerah/PAD), and poverty level on human development index (HDI) improvement. The locus for this research is all regencies/cities in Indonesia that use panel data. The results of this research were divided into three findings. First, there were research variables with unidirectional results and significant improvement on HDI, which are physical DAK for the health and education sector, village funds, social expenditure, and PAD. Second, there were variables with unidirectional impact but it does not have a significant impact on the HDI improvement (i.e. PBI JKN). Third, there were variables with unidirectional and significant impact, such as personnel expenditure, material expenditure, capital expenditure, and poverty level.
\end{abstract}

Keywords: fiscal policy; welfare; human development index; premium assistance beneficiaries; physical special allocation fund for health and education sector; village funds

\section{Introduction}

Welfare is the goal of all state (Abbas, 2000; Ali et al. 2012; Asghar etal., 2012, Arnold and Rodrigues, 2015), including Indonesia. Welfare in a state is often associated with the distribution process of resources to the people, both in the form of cash or other benefits (Goodin et al., 2008). Distribution attempts conducted by a state aims to enable the poor to access opportunities and resources, so they can participate, compete, 
The Impact of Fiscal Policy on Welfare Improvement in Indonesia: Study of Impact of Premium Assistance Beneficiaries on The National Health Insurance, Physical Special Allocation Fund for Health Sector, Education Sector, and Village Funds to Human Development Index

and fulfill their needs properly (Arneson, 1989). To improve welfare, government role is needed by actively being involved in controlling the economy and demand at macro level, decrease unemployment as well as maintaining inflation (Keynes, 1936; Auerbach, 2012; Martinez-Vaczquez et al., 2012; Muinelo-Gallo and Roca-Sagalas, 2013; Gaspar et al. 2019). For fiscal policy to perform as its function and objectives, it needs good and comprehensive planning, designing, implementation and budget accountability. Likewise, the budget to improve welfare, must be implemented thoroughly, starting from analyzing welfare problems to fulfillment of the budget.

In terms of budgeting in the Indonesian state budget, the practice of improving welfare policies is carried out through central government expenditure (BPP), transfers to regions and village funds (TKDD), and budget financing. The implementation of activities/programs from BPP and budget financing are conducted by ministries/ institutions, while for TKDD are conducted by regional governments. This research seeks to analyse the gaps in the welfare sector and the limitation of fiscal capacity. The focus of fiscal policy in this research are social protection programs in education and health sector and several policies in TKDD in order to improve welfare. Some of the fiscal and social variables in this study are PBI JKN, physical DAK for education and health sector, village funds, region's budget expenditures (personnel, material, capital, and social expenditures), PAD, and poverty level.

This research is expected to contribute: (1) provide insights on policy-making to improve welfare; (2) develop of theoretical concepts regarding fiscal policy and fiscal decentralization toward $\mathrm{HDI}$ improvement; (3) provide information of analysis result regarding fiscal and social variables in affecting welfare improvement; and (4) from research methodology side, the research is expected to give academic contribution relating to research design, which are quantitative method regression equation with panel data model to analyze the relation between fiscal and social policy toward welfare improvement. Meanwhile, this research aims to analyse how several fiscal and social variables affect $\mathrm{HDI}$, as well as analyzing and explaining how said variables have impacts on the HDI or not.

\section{Literature Review}

Welfare is a multidimensional concept which includes material and immaterial dimensions, both objective and subjective in terms of individual and group aspects (Goodin et al,. 2008). Poverty, inequality, and welfare improvement are major issues for all countries (Celikay and Gumus, 2017). Many researchers have studied issues on effective policy to overcome welfare problems (Lewis and Ulph, 1988; Blackburn 1994; Caminada and Goudswaard, 2009; Kabubo-Mariara et al., 2013; Arnold and Rodrigues 2015; and Odusola, 2017). One of the policies in an attempt to improve welfare is fiscal policy in the social protection sector. The purpose of social protection expenditure, as an instrument of fiscal policy, is to improve welfare, through adequate distribution of income and assistance, such as direct cash transfers, assistance on food, education, health and capital as well as subsidies (Sinn, 1995).

Fiscal policy is part of public policy because the main objective of fiscal policy is to create healthy economic growth, employment, reduce unemployment, and create welfare for the people. In addition, fiscal policy is also needed to maintain price stability (Christiano and Fitzgerald, 2000, Wren-Lewis, 2011) in order to maintain the purchasing power of the poor. Meanwhile, regarding the policies in social protection sector to improve welfare, there are several programs that can be implemented by the 
government. The social protection program can be in the form of cash transfers or in-kind transfers. The cash transfer program aims to improve welfare in short term by fulfilling basic needs and maintain purchase power. Meanwhile in-kind transfer in the form of education and health assistance are for long terms by improving human resource quality. According to the research results of Lustig et al. (2013), both cash and in-kind transfers can have an impact on reducing poverty and inequality if properly targeted. However, in-kind transfers (education and health) programs can have a more significant impact than cash transfers in reducing poverty and income inequality, because education and health are long-term investments that can improve the quality of human resources. This is also in line with the research result from Bourguignon (2004) which states that expenditures on education and health functions can effectively reduce inequality. An increase in expenditure on education and health will reduce inequality, the distribution of income increases for the poor due to the increase in the expenditure, which is a longterm and progressive investment in improving human resources (Chu, 2000).

In addition to social protection, education, and health programs, there are other fiscal policies which can improve welfare, one of which is through transfers to regions in the context of fiscal decentralization (Cavusglu and Dincer, 2015). Decentralization is a tool to achieve one of the goals of the state, primarily providing better public services and creating a more democratic public decisionmaking process (Jaya, 2021: 125). The background of decentralization is not only to lessen the authority of central government in controlling the regional government but it is more fundamental than that, which encourage regional government to respond quicker and better to problems on their region (Bardhan, 2002). According to Oates (1999) there are four reasons of decentralization policy implementation, which are economic efficiency, cost efficiency, accountability, and funding sources mobilization. In this case, economic efficiency is the resource allocation efficiency, i.e., decisions made by a smaller scope of government results in the types and levels of public services that are more in line with local preferences, especially if the needs between regions are relatively different (Wallis and Oates, 1988; Oates, 1999).

There are several studies fiscal decentralization effect on economic growth, poverty reduction, and income inequality in various contexts, both in developed and developing countries (Oates, 1972; Prud'homme, 1995; Tanzi, 2000; RodriguezPose and Gill, 2004; Arze et al., 2005; Ezcurra and Rodriguez-Pose, 2009; Sepulveda and Martinez-Vazquez, 2011; Tselios et al., 2011; Ali et al., 2012; Gadenne and Singhal, 2014; Cavusoglu and Dincer, 2015; Ostwald et al., 2016; Shahzadand Yasmin, 2016; Dwicaksono and Fox, 2018 ). Fiscal decentralization can improve welfare of the people in the regions through increasing regional income (both from transfer funds and $P A D$ ), improving services to the community, building facilities and infrastructure, and providing targeted assistance to the poor (Gadenne and Singhal, 2014). Fiscal decentralization can also have an effect on improving public health because decentralization can further improve health services in the regions (Dwicaksono and Fox, 2018). According to the research by Cavusoglu and Dincer (2015), the relationship between fiscal decentralization and poverty alleviation and inequality depends on the conditions or context of each country. Fiscal decentralization can reduce poverty and inequality, especially in developed countries (Cavusoglu and Dincer, 2015). Meanwhile, based on the research result from Shahzad and Yasmin (2016), it was stated that fiscal decentralization could actually increase poverty and income inequality in the regions. This is because the local government has not implemented a good governance system, 
The Impact of Fiscal Policy on Welfare Improvement in Indonesia: Study of Impact of Premium Assistance Beneficiaries on The National Health Insurance, Physical Special Allocation Fund for Health Sector, Education Sector, and Village Funds to Human Development Index

so there is no efficiency in the government management and public services.

According to Brosio and Ahmad (2006), there are several typologies of transfer to the regions, and each has different implications for incentives and distribution. Some of these typologies are listed as follows: 1) Transfers to fill local government deficits, which is performed since the revenues are smaller than the expenses (the example of general allocation fund); 2) Revenue sharing to ensure vertical fiscal balance between the central government and regional government (the example of sharing revenue fund): 3) Transfers for special purposes, transfers from the central government to local governments with a specific purpose, example special purpose allocation fund, regions incentive fund, and special autonomy fund; and 4) Transfers for balancing as a form of transfer based on regulations with balances depending on tax revenues and/ or the expenditure needs, example sharing revenue fund.

Transfer expenditures to regions that are directed to improve development and community welfare in the regions can be made in the form of special allocation funds (DAK) and village funds. DAK is divided into physical DAK and non-physical DAK. It is directed to support national priorities which has turn into regional affairs. In order to support development in education and health sector regionally, physical DAK in education and health sectors is allocated. Meanwhile, village funds are directed at improving the welfare of rural communities and their quality of life as well as poverty alleviation.

\section{Development of Welfare Policy in Indonesia}

Social protection policies in Indonesia have developed rapidly in recent years, and since 2002 the rights and access to social security have increased and developed formally (Kaasch, Sumarto, and Wilmsen,
2018). After the Asian economic crisis in 1997, Indonesia moved towards a social protection system from an exclusive system (only focusing on the formal worker sector) to a system that is universal for all Indonesians by the enactment of Act of the Republic of Indonesia Number 40/2004 concerning the National Security System (Kaasch et al., 2018, Sumarto, 2013, Suryahadi et al., 2017).

The history of social protection in Indonesia after independence began during the era of President Soekarno (19451967), with the enactment of: (1) Act of the Republic of Indonesia Number 33/1947 in conjunction with Act of the Republic of Indonesia Number 2/1951 concerning Labor Accidents; (2) Regulation of the Minister of Labor Number 48 of 1952 in conjunction with Regulation of the Minister of Labor Number 8 of 1956 concerning the Arrangements of Labor Workers Assistance; (3) Regulation of the Minister of Labor Number 15 of 1957 concerning the Establishment of the Labors' Social Foundation; (4) Regulation of the Minister of Labor Number 5 of 1964 concerning the Establishment of the Social Security Fund Foundation; and (5) Act of the Republic of Indonesia Number 14/1969 concerning the Labors Fundamental. Social protection in the Soekarno era was still limited to formal labors, while other than the group are not legally protected (juridically).

Meanwhile, during the reign of President Soeharto (1967-1998), the social security program prioritized the provision of social security for groups of state apparatus such as civil servants/national police/military and formal workers. Social protection programs for civil servants/national police/military are in the form of health insurance programs (Askes), armed forces insurance (Asabri), and pension programs, while for formal workers receive labours social insurance program (Astek) or workers social insurance (Jamsostek). The Jamsostek program which consisted of social security, labor accident insurance, death insurance, health care 
insurance, and old-age insurance.

In the era of President B.J. Habibie (1998-1999), to overcome the impact of the economic crisis in Indonesia, the government implemented the social safety net (SSN) program within the framework of the structural adjustment program required by the World Bank. President B.J. Habibie also ratified 7 basic labor standards of the International Labor Organization which are the foundation for social protection for the working class. There are various SSN programs, such as education, health, special market operations-rice, regional empowerment program-impact of economic crisis, development program for supporting disadvantaged villages, district development program, and the urban poverty alleviation program.

During the era of President Abdurrahman Wahid (1999-2001), the government signed the international agreement on the Millennium Development Goals in September 2000. In addition, President Abdurrahman Wahid's contribution was to develop a national action plan to eliminate violence against women, which includes a social protection scheme for women. Moreover, during the reign of President Megawati (2001-2004), the government enacted Act of the Republic of Indonesia Number 40/2004 concerning the National Social Security System which commend every citizen to obtain health insurance, accident protection insurance, death insurance, old age insurance, and pension insurance.

During the era of President Susilo Bambang Yudhoyono or SBY (2004-2014), the government established the National Poverty Alleviation Strategy (NPAS). The NPAS document is prepared in a participatory manner with a human rightsbased poverty approach in which guarantees the fulfillment of social protection as a human right. In 2005-2007 as compensation for the increase in fuel prices, the government distributed various social assistance programs such as health care insurance for the poor, the national program for community empowerment, and direct cash assistance. In this era health insurance programs initiated by local governments began to develop. In 2008, a public health insurance system and childbirth insurance are implemented. Then in 2010, SBY established the formation of Acceleration of Poverty Alleviation National Team to coordinate policies to accelerate poverty alleviation related to social protection across sectors. Subsequently in 2011, the government enacted Act of the Republic of Indonesia Number 9/2011 concerning the Implementation of Social Welfare and Act of the Republic of Indonesia Number 13/2011 concerning Handling of the Poor and Needy. After being delayed for 10 years, finally President SBY at the end of his leadership, starting January 1, 2014 implemented the National Social Security System Law, which consists of the national health insurance program by BPJS Health and the employment guarantee program by BPJS Employment.

Moreover, in the era of President Joko Widodo, on his first period (2014-2019), at the beginning of his leadership, President Jokowi implemented several social protection programs known as the Sakti Card, which are the Healthy Indonesia Card, Smart Indonesia Card, and Family Welfare Card. In 2015, Jokowi issued a policy of reducing fuel subsidies and diverting the subsidies to finance infrastructure development, productive programs, and increasing the budget allocation for social assistance programs, particularly in education and health sector.

As a respond to the impact of the Covid-19 pandemic, the government provides regular social protection programs and nonregular social protection programs to protect the purchasing power of the poor (Sumarto and Ferdiansyah 2021). The regular social protection program has been implemented 
The Impact of Fiscal Policy on Welfare Improvement in Indonesia: Study of Impact of Premium Assistance Beneficiaries on The National Health Insurance, Physical Special Allocation Fund for Health Sector, Education Sector, and Village Funds to Human Development Index

previously but adjusted some of its attributes such as the amount of benefits, the coverage of target beneficiaries (KPM), the scope of the program area, and the proportions for its distribution. Meanwhile, the non-regular social protection program is a program that was just initiated in 2020 as a respond to the impact of the Covid-19 pandemic.

\section{Indonesian Welfare Budget Management}

Indonesian social assistance programs vary in different sectors, such as programs in food, education, health, energy, social and economics, housing, agriculture, marine and fisheries sectors. The diversity of the program becomes an advantage as well as a challenge in its implementation. The advantage of the programs is that there are many aspects of human development that are accommodated by these various programs. On the other hand, the complex program management and the databases used in the programs become a challenge in program implementation since they can affect the effectiveness of the program.

\section{Table 1. Government Assistance Program Summary, 2014-2019}

\begin{tabular}{lll}
\hline No. & Programs & Account Type \\
\hline Programs in Food Sector & \\
1. Rice Assistance Program & Social Assistance \\
2. Noncash Food Assistance/Staple Food Card & Social Assistance \\
\hline
\end{tabular}

\section{Programs in Education Sector}

1. Program Indonesia Pintar (Smart Indonesia Program) Social Assistance

2. Bidikmisi Social Assistance

Programs in Health Sector

1. Program Indonesia Sehat (Healthy Indonesia Program) Social Assistance

$\begin{array}{lll}\text { Programs in Energy Sector } & \\ 1 . & \text { Electricity Subsidy } & \text { Subsidy } \\ 2 . & 3 \mathrm{~kg} \text { LPG Subsidy } & \text { Subsidy }\end{array}$

Programs in Social and Economy Sector

1. Program Keluarga Harapan (Family Hope Program) Social Assistance

2. Community-Based Economic Enterprises Social Assistance

3. Remote Indigenous Communities Social Assistance

4. The Strengthening Meetings between Children and Families Social Assistance

5. Social Assistance for Severe Disability Social Assistance

6. Social Assistane for Neglected Elderly Social Assistance

\begin{tabular}{lll}
\hline Programs in Housing Sector & \\
1. & Renovation Program for Uninhabitable House & Social Assistance \\
2. & Independent Housing Stimulus Assistance & Social Assistance \\
3. & Housing Loan Liquidity Facilities & Budget Financing \\
4. & Interest Difference Subsidies & Subsidy \\
5. & Down Payment Subsidy & Subsidy \\
\hline
\end{tabular}




\begin{tabular}{lll}
\hline No. & Programs & Account Type \\
\hline \multicolumn{2}{l}{ Programs in Agriculture Sector } & \\
1. $\quad$ Fertilizer Subsidy & $\begin{array}{l}\text { Subsidy } \\
\text { Social Assistance } \\
\text { 2. Insurance Premium Assistance For Rice Farmers }\end{array}$ & Social Assistance \\
3. Insurance Premium Assistance For Cow Farmers & \\
\hline $\begin{array}{ll}\text { Programs in Marine and Fisheries Sectors } \\
\text { 1. Insurance Premium Assistance for Fisherman }\end{array}$ & Social Assistance \\
2. & Fisheries Insurance Premium Assistance for Small Fish & Social Assistance \\
\hline
\end{tabular}

Source: Ministry of Finance of the Republic of Indonesia

Each social assistance program in each sector has a different goal. Their objectives are listed in the following table.

Table 2. The Objectives of Social Assistance Programs in Different Sectors

\begin{tabular}{|c|c|c|}
\hline No. & $\begin{array}{l}\text { Social Assistance } \\
\text { Program }\end{array}$ & Objectives \\
\hline 1. & Food Sector & $\begin{array}{l}\text { Reduce spending burden of the underprivileged to meet basic } \\
\text { food needs, especially rice, protein and energy sources. }\end{array}$ \\
\hline 2. & Education Sector & $\begin{array}{l}\text { Realizing the government's commitment in education sector } \\
\text { by providing education services without discrimination for all } \\
\text { citizens. }\end{array}$ \\
\hline 3. & Health Sector & $\begin{array}{l}\text { Provide comprehensive health insurance for all Indonesian } \\
\text { people so they can live healthy, productive, and prosperous. }\end{array}$ \\
\hline 4. & Energy Sector & $\begin{array}{l}\text { Provide assistance for underprivileged people (targeted } \\
\text { households) in the energy sector. }\end{array}$ \\
\hline 5. & $\begin{array}{l}\text { Economic and Social } \\
\text { Sector }\end{array}$ & Improve living standard and productivity of beneficiaries. \\
\hline 6. & Housing Sector & $\begin{array}{l}\text { Provide assistance in the form of repairing uninhabitable } \\
\text { housing, housing finance assistance, and stimulants for low- } \\
\text { income households. }\end{array}$ \\
\hline 7. & Agriculture Sector & $\begin{array}{l}\text { Provide fertilizer subsidy, as well as assistance for insurance } \\
\text { premiums for farming and livestock. }\end{array}$ \\
\hline 8. & $\begin{array}{l}\text { Fisheries and Maritime } \\
\text { Sector }\end{array}$ & $\begin{array}{l}\text { Provide fisherman and fishery insurance premium assistance } \\
\text { for small fish cultivators. }\end{array}$ \\
\hline
\end{tabular}

Based of the evaluation of the above programs implementation, it can be conveyed that the framework of each program is quite varied, including the database used, criteria of the beneficiaries, and the distribution system. The main issue in the distribution is that the database has incomplete and not updated information, thus affecting the accuracy of the targets. Also, the current social protection program system is still implemented per sector and has not been able to demonstrate synchronization between each programs and the continuity of poverty alleviation. 
The Impact of Fiscal Policy on Welfare Improvement in Indonesia: Study of Impact of Premium Assistance Beneficiaries on The National Health Insurance, Physical Special Allocation Fund for Health Sector, Education Sector, and Village Funds to Human Development Index

The current social protection policy in Indonesia refers to the Act of the Republic of Indonesia Number 11/2009 concerning Social Welfare. Having provided with this regulation, the government embodies several social protection programs as shown in Table 1. In addition, there are several welfare improvement programs through TKDD, such as village funds and DAK. Village funds in accordance with Act of the Republic of Indonesia Number 6/2014 concerning Villages, are aimed to improve the welfare of rural communities and the quality of human life as well as poverty alleviation through meeting basic needs, building village facilities and infrastructure, developing local economic potential, and utilizing natural and environmental resources sustainably. Regular physical DAK is directed to achieve minimum service standards and fulfilling basic service gaps in education, health, and connectivity. Meanwhile, the assigned physical DAK supports programs to achieve major project targets and certain priorities, which are reducing maternal mortality and stunting, poverty alleviation, food security, and sustainable economic infrastructure. For non-physical DAK, it is directed to increase and equitable distribution of health service capabilities regionally, and support the achievements of several other fields, such as food and agriculture security, increasing cooperatives and micro small and medium enterprises, and tourism services.

The challenge of implementing fiscal decentralization is that there are still gaps in development and the quality of public services. The development gap can be seen from several indicators, namely: (1) Java's contribution is still high in the economy; (2) the decline in stunting is still relatively slow, in 2018 by 30.80 percent to 27.67 percent in 2019; (3) correlation between funding and outcome is still weak; and (4) not yet synchronized between central and regional planning. Meanwhile, the gap in the quality of public services in 2019 is indicated by the participation rate of the nation Junior High School of 79.40 percent, the highest at 86.75 percent (Bali) and the lowest at 57.19 percent (Papua). In addition, the gap in the quality of public services can also be seen from the level of basic immunization, nationally at 92.96 percent, the highest at 100 percent (West Nusa Tenggara) and the lowest at 49.64 percent (Aceh).

\section{Research Method}

The analysis for this study uses a panel data with equation regression model with consideration of the short data series (20152018), but the cross section data is large (514 districts/cities) so that the data becomes more stable. In the panel data equation model, the stages of selecting the best model are conducted, whether to use the common effect model (CEM) or the fixed effect model (FEM) or the random effect model (REM). An explanation of the technique to estimate model parameters with panel data is as follows: first, the CEM, which is to estimate the parameters of the panel data model. The method is by combining cross section and time series data as a single unit without looking at the time and individual differences. Second, the FEM is to estimate panel data by using dummy variables to capture differences in intercepts between districts/cities, but the intercepts are the same over time. This model also assumes that the slope remains between districts/cities. Third, the REM is to estimate panel data in which the disturbance variables may be interrelated over time and between individuals. There are three tests to choose the panel data estimation technique, namely the Chow test, Hausman test, and the Lagrange Multiplier test.

In this study, the quantitative data used are districts/cities HDI, districts/cities physical DAK allocation for health and education, districts/cities PBI JKN, districts/ cities village funds, region's budget allocation for personnel expenditure, region's budget 
allocation for capital expenditures, region's budget allocation for material expenditures, region's budget allocation for social expenditure, poverty level in districts/cities, and districts/cities PAD. The secondary data sources used in this study are financial notes and state's budget documents, Ministry of Finance website, Indonesian Statistics Agency (BPS) website, and regulatory documents related to the research.

\section{Analysis on Impact of PBI JKN, Physical DAK for Health Sector, Physical DAK for Education Sector and Village Funds toward Human's Development Index}

Theories and research which underlie the formulation of this research equation include the theory of Keynes (1936) which states that the government should intervene in controlling an economy. According to Barro (1989), fiscal policy in the form of government expenditure can encourage economic growth, which in turn will be able to improve welfare. Government assistance to the poor in small amounts will have an insignificant impact, but assistance in sufficient amounts can have a greater impact (Devereux et al., 2000). Another finding from Imide and Onokero's research (2019) states that the total government expenditure does not significantly affect the HDI, because the amount of expenditure is relatively small compared to the need to increase the HDI. Moreover, the low transparency and accountability towards the government expenditure great affect the success of budget implementation on welfare improvement. Investments in improving human resources such as education expenditure can increase HDI (Ali et al., 2012).

Meanwhile, the relationship between the impact of fiscal decentralization on economic growth and welfare was presented by several researchers, such as Oates (1993) stated that fiscal centralization has negative and significant impact related to the level of income per capita. Meanwhile, Halder (2007) stated that fiscal decentralization in general has a positive correlation with economic outcomes (HDI, life expectancy, GDP, and infant mortality). Another study conducted by Mehmood and Sadiq (2010) regarding the effect of fiscal decentralization on the HDI, stated that fiscal decentralization both in terms of expenditure and revenue had a positive effect on HDI, and fiscal decentralization from expenditure side provide more effective impact.

The impact of state expenditure on distribution sector has an effect on material and services distribution to poor people. PBI JKN provided to the poor lead them to benefit from the free healthcare. State expenditure on education/vocational education for the poor can improve their education so it is expected they will have a better chance to access labor and eventually improve their living standard. Meanwhile, regarding the impact of fiscal decentralization on improving welfare, it confirms that fiscal decentralization has an important role in providing material that are not provided by the private sector, such as road infrastructure, dams, health, and education infrastructure which can improve the people's living standards. Fiscal decentralization is expected to increase efficiency, because local governments have better information on the needs of their communities compared to the central government.

Based on the above framework, a study was conducted on the impact of fiscal policy on welfare improvement in all district/city in Indonesia by using the following research variables and regression equations, as follows. 
The Impact of Fiscal Policy on Welfare Improvement in Indonesia: Study of Impact of Premium Assistance Beneficiaries on The National Health Insurance, Physical Special Allocation Fund for Health Sector, Education Sector, and Village Funds to Human Development Index

1. Impact of physical DAK for health \& education sector and PBI JKN on HDI model:

$H D I=f(p h y s i c a l ~ D A K$ for health sector, physical DAK for education sector, $\mathrm{PBI} J K N)$

$\ln$ (hdi) c In(dakhealth) $\ln ($ dakeducation)

$$
\ln (\mathrm{pbi}) \ln (\mathrm{res}) \ldots \ldots \ldots \ldots \ldots \ldots
$$

2. Impact of physical DAK for health \& education sector and village funds on HDI model:

$\mathrm{HDI}=\mathrm{f}$ (physical DAK for health sector, physical DAK for education sector, village funds)

In(hdi) c In(dakhealth) In(dakeducation) In(villagefunds) In(res)

3. Impact of physical DAK for health \& education sector, regional budget (APBD) expenditures, PAD, and poverty on HDI model:

$H D I=f$ (physical DAK for health sector, physical DAK for education sector, APBD's personnel expenditure, APBD's material expenditure, APBD's capital expenditure, APBD's social expenditure, PAD, poverty)

In(hdi) c In(dakhealth) In(dakeducation) In(personnelexp) $\ln ($ materialexp) In(capitalexp) $\ln$ (socialexp) In(pad) In(poverty) $\ln$ (res)

The model were divided into three because when it was combined into one model, there were independent variables which have a strong relationship with one another (multicollinearity), even though the variable transformation (first difference) had been carried out. Furthermore, the model was divided into three based on the theory that the health and education budget, and fiscal decentralization affect the level of welfare. After the exercise, the three models were free from multicollinearity and were indicated by a high $\mathrm{R}$-Square value. Meanwhile, the physical DAK for health and education sectors is always included in the model because the direction of the coefficient and its significance is always consistent and in line with the theory in supporting HDI improvement.

Before the regression and analysis of the results were performed, the model selection was done prior to obtain the best model. The stages tare listed as follows: (1) stationary test of research data, correlogram test, and unit root test to find out whether the data from research variables were stationary or not, as well as statistical descriptions to see the characteristics of the research data; (2) the stages of selecting the best model, CEM or FEM or REM; and (3) regression equation model.

Based on correlogram and unit root test, it is concluded that all the research data are stationary. Furthermore, the stationary research data was analyzed through various stages, starting from the selection of the best model, the regression model, and the analysis/interpretation of the regression results.

\section{The Impact of PBI JKN on HDI}

To discover the impact of PBI JKN on $\mathrm{HDI}$, the regression progress was performed to equation model (1), which is the impact of physical DAK for health sector, physical DAK for education sector and $\mathrm{PBI} J \mathrm{JKN}$ on the HDI. Based on the finding of the best model, REM model is obtained. 
Ahmad Nawawi, Wihana Kirana Jaya, Mulyadi Sumarto, Evita Hanie Pangaribowo

Table 3. Regression Result of the Relation between HDI on Physical DAKfor Health Sector, Physical DAK for Education Sector and PBI JKN Model

\begin{tabular}{crrrl}
\hline Variable & Coefficient & Std. Error & t-Statistic & Prob. \\
\hline c & 3.485758 & 0.022499 & 154.9279 & 0.0000 \\
dakkhealth & 0.028809 & 0.000411 & 70.09576 & 0.0000 \\
dakeducation & 0.000338 & 0.000195 & 1.733213 & 0.0832 \\
Pbi & 0.000982 & 0.000931 & 1.054788 & 0.2917 \\
res & -0.028292 & 0.000388 & -72.82512 & 0.0000 \\
\hline
\end{tabular}

\begin{tabular}{lll}
\hline $\mathrm{R}^{2}$ & $=0.801399$ & F-Stat $=1645.359$ \\
Adj. $\mathrm{R}^{2}$ & $=0.800912$ & Prob. (F-Stat) $=0.000$ \\
$\mathrm{D}$ Watson Stat & $=1.56399$ & ") Significancy level at $5 \%$ \\
In(hdi) & $=3.486+0.029 \ln ($ dakhealth $)+0.0003 \ln ($ dakeducation $)+$ \\
& & $.001(\operatorname{Inpbi})-0.28 \ln ($ res $)$
\end{tabular}

Based on the result of the regression of the model equation, PBI JKN gives a positive impact on the HDI improvement, but it is not statistically significant (probability of 0.29 ). The PBI JKN impact on HDI improvement is in accordance with the theory that health sector budget can improve people's health which then improve the quality of human development (Lustig et al., 2013; Bourguignon, 2004; Chu, 2000). The PBI JKN budget is a budget for JKN contribution assistance to the poor. The poor can access health facilities with JKN PBI assistance, so they are certain about health services. Health is one of the components of the HDI, thus if the quality of health increases, the HDI level will also increase.

Based on the regression, it shows that every 1 percent increase in the PBI JKN budget can increase the $\mathrm{HDI}$ by 0.001 percent. The insignificant and small PBI JKN coefficient on the increase in HDI is caused by several things, including: (1) health facilities that are not evenly distributed throughout Indonesia, so that it is difficult for people who receive $\mathrm{JKN}$ PBI in the regions to access health facilities and services; (2) the beneficiaries are still not on target (exclussion error), because based on data as of February 2020, from 98.6 million PBI participants,

there are still 30 million people who are not included in Data for Social Welfare (DTKS); and (3) preventive activities in health care have not been carried out optimally by the government.

The Impact of Physical DAK for the Education Sector on HDI

Based on the results of the regression of the model equations (1), (2), and (3), the increase in the physical DAK budget for education sector has a positive and significant impact on the improvement of HDI. In equation (1) the significance level is above 90 percent, while in equations (2) and (3) the significance level is in 99 percent. The impact of the physical DAK budget for education on $\mathrm{HDI}$ is in accordance with the theory that the education budget can increase the quality of human resources (Jaya, 2021; Cavusglu and Dincer, 2015; Gadenne and Singhal, 2014; Lustig et al., 2013; Bourguignon, 2004; Chu, 2000). The physical DAK budget for education is a transfer budget to the regions that is given to regional governments for the development and provision of educational facilities and infrastructure, thus the teaching and learning process is expected to be implemented better and is expected 
The Impact of Fiscal Policy on Welfare Improvement in Indonesia: Study of Impact of Premium Assistance Beneficiaries on The National Health Insurance, Physical Special Allocation Fund for Health Sector, Education Sector, and Village Funds to Human Development Index

to improve the quality of learning activities. Education is one of component on HDI, thus if the quality of education increases, the HDI level will also increase.

Based on the results of the regression of the model equations (1), (2), and (3), it shows that every 1 percent of budget increase in physical DAK in education sector can increase HDI level by $0.0003-0.002$ percent. The range of coefficients was found due to differences in the components ot the independent variables in each model. Based on the regression result above the impact of physical DAK for education sector on $\mathrm{HDI}$ improvement is relatively small. This is caused by the total budget for physical DAK in the education is relatively small, where in 2017 it was only 1.83 percent and in 2018 it was 2.05 percent from the total education budget. The total education budget in 2017 was IDR419.8 trillion and in 2018 was IDR442.2 trillion, while the physical DAK for education sector budget was IDR7.7 trillion and IDR9.1 trillion, consecutively (source: Financial Notes and State Budget, 2018). The small impact of physical DAK in education sector is in accordance with Devereux et al. (2000), Imide and Onokero (2014) research which state government budget/assistance to underprivileged citizens in small amount will give insignificant impact but assistance in sufficient amount will be more significant. Physical DAK for education sector is directed to conceptualize fulfillment in providing school facilities and infrastructure which is realized through the construction of educational facilities and infrastructure at the Early Childhood Education Centre (PAUD), Elementary School (SD), School for Disabled Children (SLB), Place for Learning Activities (SKB), Junior High School (SMP), Senior High School (SMA), and Vocational High School (SMK) levels.

Beside the relatively small proportion of the budget, the significance impact of physical DAK for the education sector on the HDI is also affected by the effectiveness of the budget realization. Based on the evaluation results of the implementation of the physical DAK for the education sector in several regions, there is still a mismatch between the programs/activities provided by the central government and the actual need for facilities and infrastructure by each school. For the sake of future improvement, the physical DAK budget allocation for the education sector should be based on proposals from each school compiled by the regional education office, and then proposed to the central government. This mechanism is expected to minimize the inaccuracy of targets, and the budget allocation will be in accordance with the real needs of each school.

\section{The Impact of Physical DAK for the Health Sector on HDI}

Based on the results of the regression of the model equations (1), (2), and (3), the increase in the physical DAK budget for health sector has a positive and significant impact on the HDI improvement, as well as in all significant equations in 99 percent. The positive impact of physical DAK for health sector on the HDI is in accordance with the theory that the health budget can improve the quality of health of the people (Jaya, 2021; Dwicaksono and Fox, 2018; Cavusglu and Dincer, 2015; Gadenne and Singhal, 2014; Lustig et al., 2013; Bourguignon, 2004; Chu, 2000), which in turn can improve the quality of human resource development. The increase in the physical DAK for the health sector budget as part of the health budget component is in line with the increase in HDI.

Based on the results of the regression of the model equations (1), (2), and (3), every 1 percent increase on the physical DAK in health sector's budget can increase HDI by $0,02-0,03$ percent. The range of coefficients is due to differences in the components ot the independent variables in each model. Its impact on $\mathrm{HDI}$ is quite significant because 
the proportion of the physical DAK budget in the health sector is relatively large to total of health budget, i.e. 15.44 percent in 2017 and 16.22 percent in 2018 (source: Financial Notes and State Budget, 2018).

In addition, the effectiveness of the physical DAK budget for health sector on the HDI improvement is also influenced by the explication of the program/activities. The activities of the physical DAK for health sector are clearly regulated in the Regulation of the Minister of Health regarding the operational instructions for the use of the physical DAK for health sector every year. In the said regulation, physical DAK for health sector is directed to activities, including: construction and rehabilitation of community health centre (Puskesmas)/hospitals; provision of health centre/hospital infrastructure; provision of health equipment for Puskesmas/hospitals; provision of facilities and infrastructure for pharmaceutical installations; supply of medicine; supply of consumables; increasing the capacity of regional health laboratories; provision of early detection tools for noncommunicable diseases; and the construction of primary hospitals. With the clarity of the operational procedure, it is very helpful for the management and effectiveness of the activites implementation of the physical DAK in the health sector.

\section{The Impact of Village Funds on HDI}

To discover the impact of village funds on the HDI, regression progress is done for the impact on physical DAK for health sector, physical DAK for education sector and village funds on the HDI. The stages of the selection process of selecting the best model are the same as the steps done in equation (1). Based on the results of the Chow test, Hausman test, and Lagrange Multiplier test, it was found that the best model was REM. Moreover, based on the REM model, the regression equation (2) is then performed.

\section{Table 4. Regression Result of the Relation between HDI on Physical DAK for Health Sector, Physical DAK for Education Sector, and Village Funds Model}

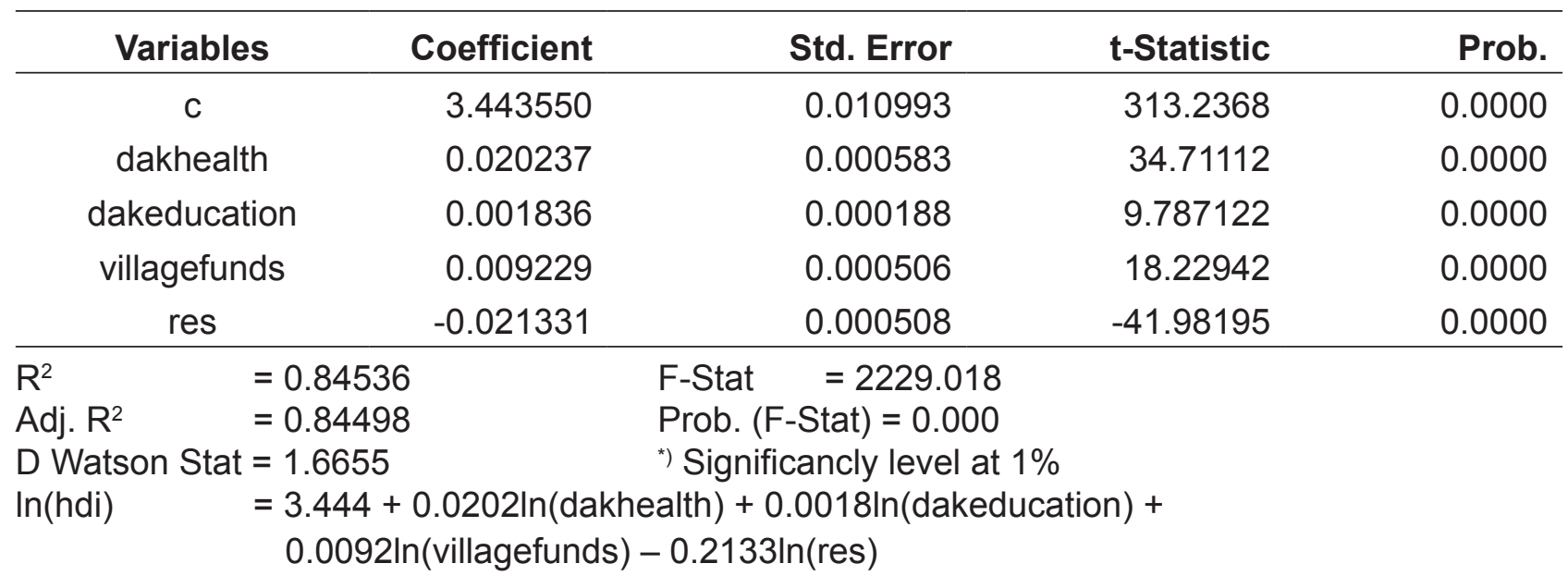

Based on the results of the regression of model equation above, the increase in the village fund budget has a positive and significant impact on $\mathrm{HDI}$ improvement (probability equation of $<0.01$ ). Based on the results of the regression equation (2), it shows that every 1 percent increase in the village fund budget can increase the HDI by 0.01 percent. The positive impact is in accordance with the theoretical literature 
The Impact of Fiscal Policy on Welfare Improvement in Indonesia: Study of Impact of Premium Assistance Beneficiaries on The National Health Insurance, Physical Special Allocation Fund for Health Sector, Education Sector, and Village Funds to Human Development Index

that the village fund budget can stimulate the quality of human development in rural communities (Jaya, 2021; Cavusglu and Dincer, 2015; Gadenne and Singhal, 2014; Lustig et al., 2013; Bourguignon, 2004; Chu, 2000). This is in line with the purpose of using the village fund budget, which is prioritized to finance development and community empowerment aimed at welfare improvement of rural communities and life quality as well as poverty alleviation.

Community empowerment activities are non-instructive efforts to encourage knowledge and ability of the community to be able to identify problems, plan, and implement solutions by utilizing local potential and existing facilities, both from sectoral agencies and non-governmental organizations as well as community leaders. Some examples of community empowerment activities are training for farmers, training on irrigating rice fields, and distributing agricultural products to small markets or cooperation. Meanwhile, to improve the quality of life, village funds are used to build integrated health centre (Posyandu), water drainage/irrigation, bathing/washing/toilet centre, PAUD buildings, reservoirs, wells, village birth centres, village roads, bridges, village markets and land holding. The fund also has a key role in decreasing poverty by infrastructure development which results in improved productivity by using local labor especially poor citizens (labor intensive).

\section{HDI Model and Other Variables}

The stage of selecting the best model for equation (3) is similar to the one done in equation (1) and equation (2). Based on the results of the Chow test, Hausman test, and Lagrange Multiplier test, it was found that the best model was FEM. Then, based of FEM model, equation regression (3) is done.

\section{Table 5. Regression Result of the Relation between HDI on Physical DAKfor Health Sector, Physical DAK for Education Sector, and Other Variables Model}

\begin{tabular}{crrrl}
\hline Variable & Coefficients & Std. Error & t-Statistic & Prob. \\
\hline c & 3.577680 & 0.013100 & 273.1108 & 0.0000 \\
dakeducation & 0.000514 & $3.33 \mathrm{E}-05$ & 15.43878 & 0.0000 \\
dakhealth & 0.029649 & 0.000102 & 289.3074 & 0.0000 \\
materialexp & -0.002181 & 0.000179 & -12.17118 & 0.0000 \\
capitalexp & -0.001212 & 0.000101 & -11.96354 & 0.0000 \\
personnelexp & -0.014071 & 0.000351 & -40.06537 & 0.0000 \\
socialexp & $7.57 \mathrm{E}-05$ & $2.51 \mathrm{E}-05$ & 3.010652 & 0.0027 \\
pad & 0.015851 & 0.000121 & 130.6578 & 0.0000 \\
poverty & -0.009880 & 0.000572 & -17.26750 & 0.0000 \\
res & -0.030141 & 0.000105 & -285.9304 & 0.0000 \\
\hline
\end{tabular}

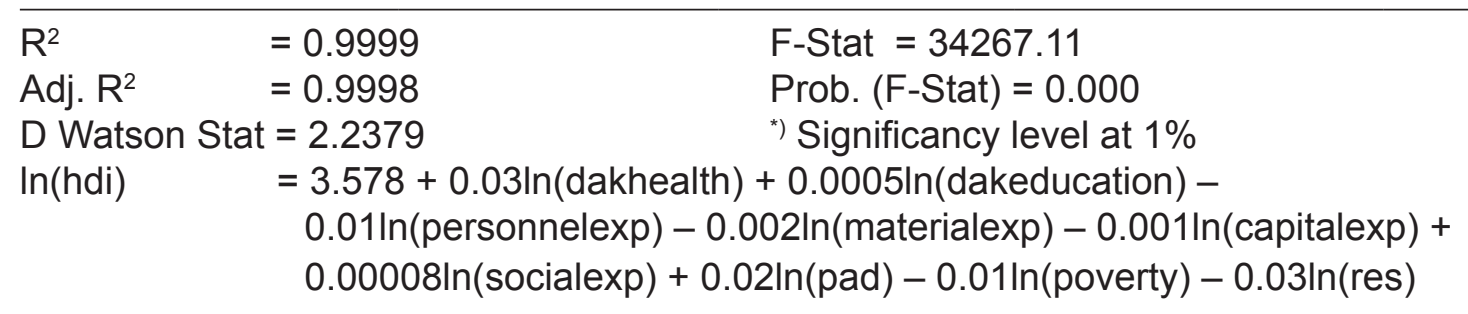


Based on the results of the regression of equation model (3), an increase in the personnel expenditure has a significantly negative impact on $\mathrm{HDI}$ improvement (probability equation of $<0.01$ ), in line with the research of Shazad and Yasmin (2016). Based on the results of the regression equation (3), it shows that every 1 percent increase in the personnel expenditure budget can decrease the HDI by 0.01 percent. The negative impact occurs because the personnel expenditure is an operational expenditure used for salary payment of regional civil servants its allocation reduces the fiscal space of local governments in allocating the budget for welfare improvement.

The budget increase for material expenditure has a negative and significant impact on the HDI (probability of all equations of $<0.01$ ), in line with the research of Shazad and Yasmin (2016). Based on the results of the regression equation (3), it shows that every 1 percent increase in the material expenditure budget can decrease the HDI by 0.002 percent. The negative impact is because material expenditure is a government expenditure used for operational activities. Similar with personnel expenditure, material expenditure reduces the fiscal space of local governments in allocating the budget for welfare improvement.

The budget increase for capital expenditure has a negative and significant impact on the HDI (probability equations of < 0.01 ), in line with the research of Shazad and Yasmin (2016). Based on the results of the regression equation (3), it shows that every 1 percent increase in the capital expenditure budget decreases the HDI by 0.001 percent. The presence of negative effect is caused by capital expenditure done by government investment expenditure, and the impact can only be felt in the medium and long term. Besides, capital budget allocation in short term reduces the fiscal space of local governments in allocating the budget for welfare improvement.
The budget increase for social expenditure has a positive and significant impact on the HDI improvement (probability equations of $<0.01$ ), in line with the research of Jaya (2021), Cavusglu and Dincer (2015), Gadenne and Singhal (2014), Lustig et al. (2013), Bourguignon (2004), Chu (2000). Based on the results of the regression equation (3), it shows that every 1 percent increase in the social expenditure budget can increase the HDI by 0.00008 percent. The small influence of social expenditure on the increasing in HDI because the proportion of the social expenditure to GDP in 2018 is small, at 0.6 percent. The small impact of social assistance, according to the research results of Devereux et al. (2000), Imide and Onokero (2019) states that a small amount of government budget/assistance to the poor will have an insignificant impact, but a sufficient amount of assistance can have a more significant impact. The positive impact occurs since the social expenditure is used for social assistance, social protection, and expenditure on poverty alleviation. Several programs included on the social assistance expenditure are Program Keluarga Harapan (family hope program), food assistance, PBI JKN assistance, Program Indonesia Pintar (smart Indonesia program), and other assistance such as assistance for the oldage and disabled. The social protection and assistance programs directly increase poor people's buying power and provide social security thus increase the development quality of the poor.

The increase on PAD has a positive and significant impact on the HDI improvement (probability equations of $<0.01$ ), in line with the research of Gadenne and Singhal (2014). Based on the results of the regression equation (3), it shows that every 1 percent increase in PAD can increase the HDI by 0.02 percent. The positive impact is because the increase in PAD can cause funding source in the regional budget to increase, thus will automatically increase the fiscal space in 
The Impact of Fiscal Policy on Welfare Improvement in Indonesia: Study of Impact of Premium Assistance Beneficiaries on The National Health Insurance, Physical Special Allocation Fund for Health Sector, Education Sector, and Village Funds to Human Development Index

allocating expenditure aimed for welfare development and improvement. PAD is a fiscal tool in the regions to carry out the function of distributing resources from the rich through taxes and is used as a source of funding for welfare development and improvement the poor in the regions.

The increase in the percentage of the number of poor people has a negative and significant impact on the HDI improvement (probability equation <0.01). Based on the results of the regression equation (3), it shows that every 1 percent decrease of the total of poor citizens can increase the HDI by 0.01 percent. This impact is in accordance with the theoretical literature, in which every decrease in the poverty rate will improve the $\mathrm{HDI}$, and vice versa (Martinez-Vaczquez et al., 2012; Muinelo-Gallo and Roca-Sagalas, 2013; Gaspar et al., 2019).

\section{Conclusion}

Based on the results of the analysis and discussion of the impact of several fiscal variables on improving welfare, the conclusion of the study can be conveyed as follows. First, there are research variables which have are unidirectional results and they are significant to HDI improvement, which are physical DAK for education and health sector, village funds, social assistance expenditure, and PAD. Second, the research variable has unidirectional results and insignificant impact on the HDI improvement (i.e. PBI JKN). Third, the research variables have directional impact and they are significant to the HDI improvement, such as personnel, material, capital expenditure, and poverty level.

Due to the limited fiscal capacity of the government, while the need for funding for development is very high, the budget allocation must be made selectively and with the right priorities. For variables that have an unidirectional and significant effect on HDI improvement, the budget allocation should be increased, but there must be a consideration for fiscal capacity, other development priorities, and fiscal sustainability. Meanwhile, for variables that have an unidirectional and insignificant effects on increasing HDI, such as the PBI JKN, there must be improvements to the implementation of the JKN PBI, such as equitable distribution of health facilities, socialization of healthy living, and validation of beneficiary data.

Furthermore, in terms of variables that have an unidirectional and significant effects, such as personnel and material expenditures, the budget must be streamlined. Personnel expenditures and material expenditures must be planned, budgeted, and implemented effectively and efficiently, and the portion of total APBD expenditures must also be reduced. Meanwhile, capital expenditures should be directed to productive capital expenditures, as well as reduced spending on office equipment and vehicles.

\section{References}

Abbas, Q. 2000. "The Role of Human Capital in Economic Growth: A Comparative Study of Pakistan and India", The The Pakistan Development Review 39:4 Part II (Winter 2010) pp. 451-473.

Ali, S. A., Raza, H., and Yousuf, U. 2012. "The Role of Fiscal in Human Development: The Pakistan's Perspective", The The Pakistan Development Review 51:4 Part II (Winter 2012) pp. 51:4, 381-396.

Arneson, R.J. 1989. "Equality and Equal Opportunity for Welfare", Philos Stud 56, 77-93.

Arnold, J. and Rodrigues, F. 2015. "Reducing Inequality and Poverty in Portugal", Economics Department Working Papers No. 1258.

Arze, F. J., Martinez-Vazquez, J., and Mcnab, R. 2005. "Fiscal Decentralization and The Functional Composition of Public Expenditures", Georgia State University: Andrew Young School of Policy Studies, International Studies Program, Working 
Paper 05-01 (Updated), September 2005.

Asghar, N., Awan, A., and Rehman, H. 2012. "Human Capital and Economic Gowth in Pakistan: A Cointegration and Causality Analysis", International Journal of Economics and Finance, Vol. 4, No. 4.

Auerbach, A. J. 2012. "The Fall and Rise of Keynesian Fiscal Policy", Asian Economic Policy Review, Vol. 7, Issue 2, pp. 157-175.

Bardhan, P. 2002. "Decentralization of Governance and Development", Journal of Economic Perspectives, Vol. 16, Number 4, Pages 185-205.

Barro, R. J. 1989. "The Ricardian Approach to Budget Deficits", Journal of Economic Perspectives 3, pp. 37-54.

Blackburn, M. L. 1994. "International Comparisons of Poverty," The American Economic Review", Papers and Proceedings of the Hundred and Sixth Annual Meeting of the American Economic Association, 84, 2, May 1994, pp 371-4.

Bourguignon, F. 2004 "The Poverty-GrowthInequality Triangle", paper was presented at The Indian Council for Research on International Economic Relations, New Delhi, on February 4, 2004.

Brosio, G. and Ahmad, E. 2006 "Uganda: Managing More Effective Decentralization", IMF Working Paper No. 06/279.

Caminada, K. and Goudswaard, K. 2009 "Effectiveness of Poverty Reduction in the EU: A Descriptive Analysis", Poverty and Public Policy, Vol. 1 (2): 5-5.

Cavusoglu, T. and Dincer, O. 2015 "Does Decentralization Reduce Income Inequality? Only in Rich States", Southern Economic Journal 82 (1): 285306.

Celikay, F. and Gumus, E. 2017. "The Effect of Social Spending on Reducing Poverty", International Journal of Social
Economics, Vol. 44, Issue 5, pp. 620632.

Christiano, L. J. and Fitzgerald, T. J. 2000. "Understanding the Fiscal Theory of the Price Level", FRB Cleveland - Economic Review, 2000, v36 (2, Qtr-2), 2-37.

Chu, H. Y. 2000 "The Impacts of Educational Expansion and Schooling Inequality on Income Distribution", Quertaly Journal of Business and Economics 39 (2): 39 - 49. Devereux, M. B., Head, A. C., and Lapham, B. J. 2000. "Government Spending and Welfare with Returns to Specialization", The Scandinavian Journal of Economics, Volume 102, No. 4 (Dec, 2000), pp. 547561.

Dwicaksono, A. and Fox, A. 2018. "Does Decentralization Improve Health System Performance and Outcomes in Low and Middle-Income Countries? A Systematic Review of Evidence from Quantitative Studies: Decentralization and Health System Performance and Outcomes", Milbank Quartely 96 (2): 323-368.

Ezcurra, R. and Rodríguez-Pose, A. 2009. "Does Decentralization Matter for Regional Disparities? A CrossCountry Analysis," SERC Discussion Papers 0025, Spatial Economics Research Centre, LSE.

Gadenne, L. and Singhal, M. 2014. "Decentralization in Developing Economies", National Bureau of Economic Research, Working Papers 19402.

Gaspar, V., Amaglobeli, D., Garcia-Escribano, M., Prady, D., and Soto, M. 2019. "Fiscal Policy and Development: Human, Social, and Physical Investment for the SDGs", IMF Staff Discussion Note SDN/19/03, Fiscal Policy and Development.

Goodin, R., Rice, J., Parpo, A., and Eriksson, L. 2008. Discretionary Time: A New Measure of Freedom, Cambridge University Press.

Halder, P. 2007. "Measures of Fiscal Decentralization", Andrew Young 
The Impact of Fiscal Policy on Welfare Improvement in Indonesia: Study of Impact of Premium Assistance Beneficiaries on The National Health Insurance, Physical Special Allocation Fund for Health Sector, Education Sector, and Village Funds to Human Development Index

Scholl of Policy Studies, Georgia State University.

Imide and Onokero, I. 2019. "The Impact of

Fiscal Policy on Human Development Index: Empirical Evidence from Nigeria's Democratic Era", International Journal of Economics, Commerce and Management, United Kingdom, Vol. VII, Issue 2.

Jaya, W. K. 2021. Ekonomi Kelembagaan dan

Desentralisasi, Gadjah Mada University Press.

Kaasch, A., Sumarto, M., and Wilmsen, B. 2018. "Indonesian Social Policy Development in a Context of Global Social Governance", prepared for the UNRISD project, New Directions in Social Policy: Alternatives from and for the Global South.

Keynes, J. M. 1936. The General Theory of Employment, Interest and Money, reprinted in Keynes, Collected Writing, Vol. 6.

Lewis, G. W. and Ulph, D. T. 1988. "Poverty, Inequality and Welfare", The Economic Journal, Vol. 98, Issue 390, 1 April 1988, pages 117-131.

Lustig, N., Pessino, C., and Scott, J. 2013. "The Impact of Taxes and Social Spending on Inequality in Argentina, Bolivia, Brazil, Mexico, Peru, and Uruguay: Introduction to the Special Issue", Commitment to Equity, Working Paper No. 13.

Martinez-Vazquez, J., Claus, I., and Vulovic, V. 2012. "Government Fiscal Policies and Redistribution in Asian Countries", Economics Working Papers, Asian Development Bank.

Mehmood, R., Sadiq, S., and Khalid, M. 2010. "Impact of Fiscal decentralization on Human Development: A Case Study of Pakistan", The Pakistan Development Review, Vol. 49, No. 4, Papers and Proceedings PARTS I and II The 26th Annual General Meeting and Conference of the Pakistan Society of Development
Economist Islamabad, December 28-30, 2010 (Winter 2010), pp 513-530.

Muinelo-Gallo, L. and Roca-Sagalas, O. 2013. "Economic Growth, Inequality and Fiscal Policies: A Survey of Macroeconomic Literature", [S. I.]: Nova Science Publisher.

Republic of Indonesia. 2018. "Financial Note and State Budget 2018", Jakarta: Republic of Indonesia.

Oates, W. 1972. "Fiscal Federalism", New York: Harcourt Brace Jovanovich.

Oates, W. 1993. "Fiscal Decentralization and Economic Development", National Tax Journal, Vol. 46. No. 2 (June, 1993), pp. 237-43.

Oates, W. 1999. "An Essay on Fiscal Federalism", Journal of Economic Literature, Volume 37, Issue 3, 11201149.

Odusola, A. 2017. "Fiscal Space, Poverty and Inequality in Africa", African Development Review, Vol. 29, No. S1, 2017, 1 - 14.

Ostwald, K., Tajima, Y., and Samphantharak, K. 2016. "Indonesia's Decentralization Experiment: Motivations, Successes, and Unintended Consequences", Southesat Asian Economies 33 (2): 139156.

Prud'homme, R. 1995. "The Dangers of Decentralization", The World Bank Research Observer 10 (2): 201-220.

Rodriguez-Pose, A. and Gill, N. 2004. "Is There a Global Link between regional Disparities and Devolution?", Environment and Planning Annual, Vol. 36, No. 12, pp. 2097-2117.

Sepulveda, C. F. and Martinez-Vazquez. 2011. "The Consequences of Fiscal Decentralization on Poverty and Income Equality", Environment and Planning C: Government and Policy 2011, Volume 29, pages 321-343.

Shahzad, S. and Yasmin, B. 2016. "Does Fiscal Decentralization Matter for Poverty and Income Inequality in Pakistan?", 
Pakistan Development Review 55 (4): 781-802.

Sinn, H. 1995. "A Theory of the Welfare State", The Scandinavian Journal of Economics", Vol. 97, No. 4, The Future of the Welfare State (Dec. 1995), pp. 495-526.

Sumarto, M. 2013. "Welfare Regime, Social Conflict, and Clientilism in Indonesia", Phd Thesis, Australian National University.

Sumarto, M. 2017. "Welfare Regime Change in Developing Countries: Evidence from Indonesia", Social Policy and Administration ISSN 0144-8896, DOI: 10.1111/spol. 12340, Vol. 51, No. 6, November 2017, pp. 940 - 959.

Sumarto, M. and Ferdiansyah, F. 2021. "Indonesia's Social Policy Response to Covid-19: Targeted Social Protection Under Budget Constraints", Covid-19 Social Policy Response Series. CRC 1342/No. 28.

Suryahadi, A., Febriany, V., and Yumma, A. 2017. "Expanding Social Security in Indonesia: The Current Processes and Challenges", edited by I, Yi, 373-403, Basingstoke: Palgrave Macmillan.

Tanzi, V. 2000. "Fiscal Federalism and Decentralization: A Review of Some Efficiency and Macroeconomics Aspects", In Proceeding of the Annual World Bank Conference on Development Economics, Chapter 11, pp. 231-263, Washington D. C., World Bank.

Tselios, V., Rodríguez-Pose, A., Pike, A. J., Tomaney, J., and Torrisi, G. 2011. "Income Inequality, Decentralisation and Regional Development in Western Europe", CEPR Discussion Paper 8575.

Wallis, J. J. and Oates, W. 1988. "Decentralization in the Public Sector: An Empirical Study of State and Local Government", A Chapter in Fiscal Federalism: Quantitative Studies, pp 5-32 from National Bureau of Economic Research, Inc.
Wren-Lewis, S. 2011. "Lessons from Failure: Fiscal Policy, Indulgence and Ideology", National Institute Economic Review, Vol. 217, July 2011, pp. R31-R46. 